\title{
O Poder Político Do Judiciário: Uma Análise Histórica, Jurídica, Política E Sociológica Do Estado Liberal Ao Estado Democrático De Direito
}

\author{
Bruno Paiva Bernardes \\ Mestrando em Instituições Sociais, Direito e Democracia pela Universidade \\ FUMEC. Bolsista da Fundação de Amparo à Pesquisa de Minas Gerais (FAPEMIG). \\ E-mail: brunopbernardes@gmail.com
}

\section{Eduardo Martins de Lima}

Doutor em Ciências Humanas: Sociologia e Política. E-mail: eduardomlima.prof@gmail.com

Resumo: O presente artigo, cuja investigação se dá na vertente jurídicosociológica e tendo como raciocínios predominantes o indutivo-dedutivo e o dialético, tem como temática o poder político do Judiciário desde a parte final da Idade Moderna até a contemporaneidade. Como problema, e agregando o olhar da Ciência Política às definições jurídicas e aos acontecimentos históricos, questiona a interferência dos padrões de organização política no estabelecimento e delimitação do poder político do Judiciário, bem como as influências ideológicas no pensamento jurídico. Objetiva investigar e dimensionar o poder político do Judiciário desde o período imediatamente anterior à Revolução Francesa e à Constituição norte-americana até o surgimento do Estado Democrático de Direito, contextualizando com estudos políticos e sociológicos acerca dos perfis dos juízes no processo decisório. Afirma, como hipótese, que a existência e a dimensão do poder político do Judiciário variam conforme o paradigma jurídico vigente.

Palavras-chave: Ciência Política. História do Direito. Poder Judiciário. Poder político. Política.

\section{UNIVERSIDADE FEDERAL DA PARAÍBA}




\title{
O Poder Político Do Judiciário: Uma Análise Histórica, Jurídica, Política E Sociológica Do Estado Liberal Ao Estado Democrático De Direito
}

\author{
Bruno Paiva Bernardes
}

Eduardo Martins de Lima

\section{INTRODUÇÃO}

Em um tempo marcado pela tendência ao biografismo, como destaca Ingeborg Maus (200o, p. 185), o papel político do Poder Judiciário tem sido constantemente questionado, revisto e redefinido, ora pelas próprias práticas jurídicas atuais, caracterizadas pela aproximação do Direito e da moral, ora pela contribuição acadêmica que, apesar de repelir um juiz "boca da lei"1, como imaginava Montesquieu (2000, p. 175), investiga e propõe as balizas democráticas para o processo decisório.

Contudo, a compreensão do papel político do Poder Judiciário demanda investigação contextualizada, muito além daquilo que comumente se costuma chamar de protagonismo judicial, seja na vertente do denominado ativismo judicial, entendido aqui, segundo Cass Robert Sunstein (2005, p. 42-43), como a frequência com que determinado magistrado ou tribunal invalida as ações de outros Poderes de Estado, em especial do Legislativo, seja na vertente da

${ }_{1}$ Metáfora utilizada por Montesquieu (2000, p. 175) para se referir ao modelo judicante restrito à mera subsunção dos fatos às leis, sem sopesar ou excepcionar sua força ou rigor. 
O Poder Político Do Judiciário: Uma Análise Histórica, Jurídica...

denominada judicialização da política, compreendida como movimento de transferência ao Poder Judiciário do termo final de questões políticas relevantes (BARROSO, 2012, p. 5).

Este artigo desenvolve-se sob tal temática, i.e., o papel político do Poder Judiciário para além do mero protagonismo judicial, em recorte histórico que vai desde a parte final da Idade Moderna até a contemporaneidade. Como problema, e agregando o olhar da Ciência Política às definições jurídicas e acontecimentos históricos, questiona a interferência dos padrões de organização política no estabelecimento e delimitação do poder político do Judiciário, bem como as influências ideológicas no pensamento jurídico. Como hipótese, afirma que houve considerável variação da dimensão política do Judiciário, o que influi no processo decisório e no perfil dos juízes, sobretudo quando analisados sob o ponto de vista histórico, político e sociológico, variando a intensidade desse poder político de acordo com o paradigma jurídico vigente.

Ademais, o trabalho desenvolve-se em outros três tópicos, além desta introdução e da conclusão. O primeiro tópico aborda o papel político do Poder Judiciário na França e nos Estados Unidos da América, tendo como marco temporal, respectivamente, a Revolução Francesa e a Constituição norte-americana. Busca demonstrar como a mudança do Antigo Regime francês e do período colonial norteamericano, no período pós-Revolução e na experiência democrática dos Estados Unidos, influenciou o modelo político dos dois países e, em consequência, o papel político do Judiciário.

O segundo tópico avança um pouco mais na história, tratando, incialmente, da redefinição da função política do Poder Judiciário a partir da decadência do modelo estatal liberal, passando para o Estado do Bem-Estar (ou welfare state) e, posteriormente, no declínio desse Estado Providência e no surgimento do Estado Democrático de Direito, com destaque para a alteração no padrão de litigiosidade e para a postura política do Judiciário, verdadeiro gestor 
de crises. Aborda, ainda, a aproximação do Direito e moral e a crise paradigmática da virada do positivismo para o pós-positivismo, exemplificada, ali, pelo embate entre a escola histórica, capitaneada por Friedrich Karl von Savigny e Georg Friedrich Puctha, e as críticas a ela feitas por Rudolf von Ihering e sua "jurisprudência dos interesses" (LARENTZ, 1997, p. 63).

Na sequência, o terceiro tópico traz apontamentos sobre a contribuição da Sociologia da Administração da Justiça para a definição e compreensão do papel político do Poder Judiciário a partir do século $\mathrm{XX}$, com destaque para algumas pesquisas, nos Estados Unidos e no Brasil, que contribuíram para o entendimento da atuação jurisdicional e o impacto das ideologias, sobretudo as políticas, no processo decisório.

Ao final, o artigo apresenta conclusão reafirmando que a existência e a dimensão do poder político do Judiciário variam conforme o paradigma do Direito na modernidade, seja ele do Estado Liberal, do Estado Bem-Estar ou do Estado Democrático.

Este trabalho, assim, tem como objetivo investigar e dimensionar o poder político do Poder Judiciário desde o período imediatamente anterior à Revolução Francesa e à Constituição norteamericana, ambos de 1789 e de marcante influência na definição atual dos Poderes estatais, até o surgimento do Estado Democrático de Direito, contextualizando, ainda, com os estudos políticos e sociológicos acerca dos perfis dos juízes e do processo decisório.

O marco teórico é de conteúdo interdisciplinar (GUSTIN; DIAS, 2015, p. 38-39), com cruzamentos sobre a definição moderna do princípio da separação de Poderes de Estado, de Montesquieu, as relações de poder nas instituições estatais, tendo como foco o Poder Judiciário, além da Sociologia da Administração da Justiça, à luz do pensamento de Boaventura de Sousa Santos, acrescida da compreensão dos tribunais e juízes como um "subsistema do sistema político global” (SANTOS, 1986, p. 23). 
O Poder Político Do Judiciário: Uma Análise Histórica, Jurídica...

Quanto aos aspectos metodológicos, a produção do artigo se dá na vertente jurídico-sociológica (GUSTIN; DIAS, 2015, p. 22). Por conseguinte, a investigação se dá no tipo histórico-jurídico, pois se presta à identificação das distinções do poder político do Judiciário ao longo de corte temporal específico, e no tipo jurídicocompreensivo, pois analisa a definição desse mesmo poder político em diversos aspectos e níveis. Adota, ainda, como raciocínios predominantes, o indutivo-dedutivo e o dialético. É de perspectiva interdisciplinar, pois combina aspectos da História do Direito, da Ciência Política, da Sociologia Jurídica, da Filosofia do Direito e da Teoria do Direito.

\section{O PAPEL POLÍTICO DO JUDICIÁRIO NA REVOLUÇÃo FRANCESA E NA CONSTITUIÇÃO NORTE-AMERICANA}

Para compreensão do papel político do Poder Judiciário na contemporaneidade impõe-se buscar na história o contexto que envolveu a formulação e definição de papéis do mencionado Poder de Estado em dois relevantes marcos temporais do fim da Idade Moderna: a Revolução Francesa e a Constituição norte-americana.

\subsection{O JUDICIÁRIO NO ANTIGO REGIME FRANCÊS E NO PERÍODO COLONIAL NORTE-AMERICANO}

A ruptura política vivida com o surgimento dos estados liberais, revelou-se de essencial importância para a definição do papel político do Poder Judiciário nos sistemas jurídicos atuais, quer de tradição romano-germânica, a exemplo do Brasil, quer de ligação com a common law, como os Estados Unidos da América. 
Entretanto, na tentativa de identificar a relação entre Judiciário e política, convém, preliminarmente, investigar o papel do Judiciário antes da elaboração do princípio da tripartição de Poderes, sobretudo o modelo absolutista no Antigo Regime francês e o período colonial norte-americano.

No modelo absolutista, a França se via "[...] coberta de corpos administrativos ou de funcionários isolados" (TOCQUEVILLE, 1997, p. 77) e os Tribunais de Justiça, com sua indireta, mas considerável interferência no Poder Legislativo, ditavam regulamentos restritos aos limites de sua competência. Ainda, é possível perceber que esse diagnóstico não se limitou à França, mas se estendeu a toda Europa absolutista, como enfatiza Alexis de Tocqueville (2000), in verbis:

Não faz ainda cem anos que, na maioria das nações europeias, encontravam-se particulares ou corpos quase independentes que administravam a justiça, recrutavam e treinavam soldados, recebiam impostos e muitas vezes até faziam ou comentavam a lei. O Estado arrogou-se por toda a parte esses atributos naturais do poder soberano; em tudo o que diz respeito ao governo, ele não aceita mais intermediário entre ele e os cidadãos, e dirige-os por si mesmo nos negócios gerais (TOCQUEVILLE, 2000, p. 375).

No entanto, percebeu-se na sociedade francesa prérevolucionária um corpo administrativo de origem antiga, mas acostado ao reino, o chamado "Conselho do Rei". (TOCQUEVILLE, 1997, p. 78). A respeito de tal instituição, Alexis de Tocqueville, em 1856, afirmou:

Sua origem é antiga, mas a maior parte das suas funções é de data recente. E ao mesmo tempo supremo tribunal de justiça, pois tem o direito de cassar os decretos de todos os tribunais originários, e superior tribunal administrativo, pois todas as jurisdições especializadas são, em última instância, de sua competência (TOCQUEVILLE, 1997, p. 78). 
O Poder Político Do Judiciário: Uma Análise Histórica, Jurídica...

Ainda que a organização local pudesse resultar em modelo em que magistrados ou dirigentes regulassem os interesses locais, o Conselho do Rei personificava a própria figura do Monarca e seu poder absoluto. E, ainda que esse Conselho aparentemente externasse suas manifestações como um Corpo de justiça, em verdade sua ação era a ação do Rei, pois só o Rei decidia.

Em consequência, embora as diferentes instâncias locais ou regionais fizessem uso de decretos para fins de polícia, o Conselho do Rei "[...] sempre podia cassá-los, o que fazia frequentemente" (TOCQUEVILLE, 1997, p. 81).

Nesse contexto de centralização não é difícil perceber que o poder político dos órgãos de justiça circunscrevia-se à vontade do Monarca. O papel da Justiça, assim, no modelo absolutista francês, nunca passou de função estatal não-autônoma e, por óbvio, bem distante da experiência como poder de Estado.

O período de domínio inglês nas colônias norte-americanas não foi diferente. Nele, o poder político concentrava-se no Governador, designado pelo Rei da Inglaterra, que exercia funções executivas, legislativas e judiciárias. Esse modelo de concentração de poderes afastava a necessidade de um sistema judiciário mais elaborado (ESTADOS UNIDOS DA AMÉRICA, 2006, p. 46), com juízes locais ${ }^{2}$ nomeados pelo Governador da colônia, funcionando, acima, os tribunais dos condados, que eram tribunais de júri das colônias.

2 Também chamados de juízes de paz ou magistrados (ESTADOS UNIDOS DA AMÉRICA, 2006, p. 46). 


\subsection{A REVOLUÇÃO FRANCESA E O JUDICIÁRIO}

A Revolução Francesa, de 1789, tem como pano de fundo a expansão do capitalismo industrial do século XVIII, que diversificou a trama de relações sociais e comerciais, aliada à expansão do modelo de pensamento liberal como alternativa racional ao absolutismo reinante na Europa.

A experiência francesa foi, sem dúvida, marcante para a definição de temas como a tripartição de Poderes, construção que tem como marco teórico o pensamento de John Locke (1978), no século XVII, e Montesquieu, no século XVIII3.

Estão consagradas no livro escrito por Montesquieu e publicado em 1748, O espírito das leis (MONTESQUIEU, 2000), a divisão e a distribuição clássicas dos Poderes estatais. É em seu livro que o autor considera a exigência de se tripartir os Poderes estatais em órgãos diferenciados. Montesquieu explicita a necessidade da separação de Poderes no Capítulo V do Livro Décimo Primeiro de sua obra, vindo a fazer a distinção entre os Poderes Executivo, Legislativo e Judiciário. De acordo com Montesquieu:

Existem em cada Estado três tipos de poder: o poder legislativo, o poder executivo das coisas que dependem do direito das gentes e o poder executivo daquelas que dependem do direito civil. Com o primeiro, o príncipe ou o magistrado cria leis por um tempo ou para sempre e corrige ou anula aquelas que foram feitas. Com o segundo, ele faz a paz ou a guerra, envia ou recebe embaixadas, instaura a segurança, previne invasões. Com o terceiro, ele castiga os crimes, ou julga as querelas entre os particulares. Chamaremos a este último poder de julgar e ao outro simplesmente poder executivo do Estado (MONTESQUIEU, 2000, p. 167-168).

3 O princípio da separação de Poderes encontrou em Montesquieu (2000) seu expoente máximo. Antes, porém, pode ser encontrada em John Locke (1978) e, na origem, em Aristóteles (1979), que na Antiguidade grega, havia tratado do tema, ao distinguir a Assembleia-geral, o corpo de magistrados e o corpo judiciário (deliberação, mando e julgamento) (CARVALHO, 2011, p. 149). 
Desse modo, a separação dos Poderes, que no século XVIII ganhou projeção, representou o trunfo político que soçobrou o modelo absolutista e impulsionou o modelo de Estado liberal. Entretanto, diferenças essenciais marcaram a experiência francesa, especialmente se contrastada com a experiência norte-americana.

Havia, na França, um desejo incontido de fazer cessar toda e qualquer possibilidade de retorno ao absolutismo monárquico. Os Poderes precisavam estar separados e equilibrados, cabendo ao Legislativo fazer as leis, ao Executivo poder fazer a guerra ou a paz e ao Judiciário aplicar as leis, de modo que apenas o poder pudesse impedir os abusos do poder (GRISSAULT, 2012, p. 144).

Contudo, a Revolução na França não colocou o Poder Judiciário como efetivo contrapeso aos demais Poderes. Sua configuração estava cercada, de um lado, por um Executivo enfraquecido e no receio de retorno ao absolutismo monárquico e, de outro, por um Legislativo hipertrofiado, que se valia da máxima da lei como vontade soberana e incontestável.

Os três textos constitucionais da Revolução Francesa, respectivamente de 1791, 1793 e 1795, negaram conferir ao Poder Judiciário a prerrogativa de rever os atos do Executivo e do Legislativo.

A primeira Constituição, de 1791, fez menção às três funções de governo - Executivo, Legislativo e Judiciário - mas manteve o regime monárquico. [...] No artigo $3^{\circ}$ deixava absolutamente claro que os tribunais não tinham o direito de suspender a execução das leis. Esses dois dispositivos foram recolocados no texto de 1795 [...]. Entretanto, das três constituições, a que mais se afastou da ideia liberal de separação e equilíbrio de poderes foi aquela elaborada pelos radicais jacobinos (1793) [...]. Ao lado do sufrágio universal e de outras medidas igualitárias, o texto de 1793 estabeleceu a supremacia do parlamento como órgão da soberania popular e, com base na ideia rousseauniana da vontade geral, fixou a supremacia da lei [...] (ARANTES, 2007, p. 84, grifos no original). 
Nesse estreito espaço, restou ao Judiciário a tarefa de regular os conflitos entre particulares, uma tarefa, por si só, de reduzida feição política e distanciada dos demais Poderes.

\subsection{A EXPERIÊNCIA CONSTITUCIONAL NORTE-AMERICANA E O JUDICIÁRIO}

Se o modelo revolucionário francês, mais republicano do que liberal, assentou suas premissas na modernização da função da justiça comum do Poder Judiciário, mas sem lhe conferir poder político que o colocasse na verdadeira condição de freio dos demais Poderes, a experiência norte-americana, tendo como marco teórico e temporal a Constituição de 1787 , desenhou-se mais liberal do que republicana, erigindo o Judiciário à condição efetiva de poder político.

Os sete artigos da Constituição norte-americana e suas respectivas seções dedicaram-se a estruturar o exercício dos três Poderes, contemplando marcante independência do Judiciário nas seções 1 e 2 do artigo III:

\footnotetext{
ARTIGO III

Seção 1.

O Poder Judiciário dos Estados Unidos será investido em uma Suprema Corte e nos tribunais inferiores que forem oportunamente estabelecidos por determinações do Congresso. Os juízes, tanto da Suprema Corte como dos tribunais inferiores, conservarão seus cargos enquanto bem servirem, e perceberão por seus serviços uma remuneração que não poderá ser diminuída durante a permanência no cargo.
}

Seção 2. 
A competência do Poder Judiciário se estenderá a todos os casos de aplicação da Lei e da Equidade ocorridos sob a presente Constituição, as leis dos Estados Unidos, e os tratados concluídos ou que se concluírem sob sua autoridade; - a todas as ações que afetem os embaixadores, outros ministros e cônsules; - a todas as ações do almirantado e de jurisdição marítima; - às controvérsias em que os Estados Unidos sejam parte; - às controvérsias entre dois ou mais estados; [...] (ESTADOS UNIDOS DA AMÉRICA, 2006, p. 187, grifos nossos).

Mas o contexto que permeou a Convenção da Filadélfia de 1787 e mesmo o período posterior à vigência da constituição norteamericana, em 1789, não estava limitado a uma simples resposta ao poder absoluto. A primeira década da independência norteamericana demonstrou que mesmo os governos de uma maioria popular não estavam imunes à tirania (ARANTES, 2006, p. 83). James Madison em um dos "artigos federalistas"4, assim escreveu:

O acúmulo de todos os poderes legislativos, executivo e judiciário nas mesmas mãos, seja de uma pessoa, de algumas ou de muitas, seja hereditário, autodesignado ou eletivo, pode ser justamente considerado a própria definição de tirania. Portanto, se a Constituição federal pudesse ser realmente acusada desse acúmulo de poder, ou de misturar poderes, revelando perigosa tendência a tal acúmulo, não seriam necessários quaisquer argumentos adicionais para inspirar uma reprovação universal do sistema (MADISON; HAMILTON; JAY, 1993, p. 331-332).

Essa postura impôs maior equilíbrio entre os Poderes e não uma supremacia do Parlamento, como no modelo da separação de Poderes na França. Se, na França, o ideal da igualdade sobrepunha aos demais - ao ponto de Robespierre, líder jacobino, sugerir a igualdade como valor superior ao da propriedade -, nos Estados Unidos a liberdade foi o ponto de partida. E é na defesa das

4 Esses trabalhos eram "escritos para tentar convencer os cidadãos de Nova York a votar favoravelmente à promulgação do novo texto constitucional" (ARANTES, 2007, p. 83). 
liberdades individuais e, especialmente, no direito de propriedade, que o papel político do Judiciário norte-americano sobressaiu.

A teoria da tripartição de Poderes, ou separação de funções como alguns autores preferem, como já se observou, foi que lançou bases para o desenvolvimento do princípio de checks and balances ("freios e contrapesos"), utilizada pelos fundadores da República norte-americana, em meados do século XVIII e foi nos Estados Unidos da América que ela adquiriu a sua feição constitucional contemporânea por seus fundadores James Madison, Thomas Jefferson, George Washington, Alexander Hamilton e John Adams, denominados de "os federalistas". Assim como Montesquieu, os federalistas sustentavam ser necessária a transferência do poder das mãos de apenas uma pessoa ou órgão para os Poderes Legislativo, Executivo e Judiciário. Com o poder distribuído em três órgãos, a sociedade poderia viver em um Estado sem opressão e leis tirânicas, sendo asseguradas a liberdade dos cidadãos e a garantia dos direitos individuais, pois a fiscalização do poder pelo poder resguardaria o próprio Estado dos efeitos maléficos de uma tirania.

E, novamente Tocqueville, foi quem soube analisar as razões do sucesso da democracia norte-americana. No clássico $A$ democracia na América (TOCQUEVILLE, 2000), de 1835, sua preocupação central era indagar se a democracia poderia reconciliar a igualdade com a liberdade. Uma das razões para o sucesso do modelo democrático norte-americano, segundo ele, era a descentralização do poder, com a recriação de corpos intermediários antes suprimidos (CAMPUS et al., 2014, p. 35) e o fortalecimento do Judiciário, para ele, o único e efetivo contrapeso da democracia (ARANTES, 2007, p. 87).

A percepção de Tocqueville sobre o Judiciário norteamericano era a de um novo corpo aristocrático que, revestido de prerrogativas e privilégios, traduzia-se como "[...] a última barreira às paixões democráticas desenfreadas" (ARANTES, 2007, p. 88), razão do triunfo e sustentação do modelo de democracia na América do 
Norte, evitando uma tirania da maioria já denunciada por Madison, isto é, o poder de uma maioria, abusivamente impor decisões a uma minoria.

É dessa crença no Judiciário como efetivo contrapeso dos demais Poderes que, em 1803, sob a presidência do juiz John Marshall, foi possível a construção da decisão no paradigmático caso Marbury v. Madison, em que a Suprema Corte norte-americana estabeleceu as primeiras bases do judicial review, colocando, efetivamente, o Poder Judiciário em condição de paridade com o Executivo e o Legislativo, conferindo-lhe, assim, um importante sentido ao seu poder político.

Nessa linha é o magistério de Rogério Bastos Arantes, que afirma:

\begin{abstract}
A condição de poder político do Judiciário nos tempos modernos decorre de sua capacidade de controlar os atos normativos dos demais poderes, especialmente as leis produzidas pelo parlamento. Essa função, conhecida como judicial review ou controle de constitucionalidade das leis, coloca o Judiciário em pé de igualdade com os demais poderes, exatamente naquela dimensão mais importante do sistema político: o processo decisório de estabelecimento de normas (leis e atos executivos) capazes de impor comportamentos. Nos países em que o Judiciário ou um tribunal especial pode ser acionado para verificar o respeito das leis e dos atos normativos à Constituição, pode-se dizer que existe um terceiro poder político de Estado, ao lado do Executivo e do Legislativo. Nos países em que essa função inexiste, o Judiciário assemelha-se a um órgão público ordinário, responsável pela importante tarefa de prestar justiça nos conflitos particulares, mas incapaz de desempenhar papel político no processo decisório normativo (ARANTES, 2007, p. 84, grifos no original).
\end{abstract}

Fundando-se nessas premissas, pode-se admitir, ainda que em linhas sintéticas ou superficiais, que se há judicial review, há poder político no Judiciário. No oposto, a restrição à revisão de atos dos demais Poderes no controle de constitucionalidade, implica em restringir o Judiciário à mera condição de regulador dos conflitos entre particulares. 


\title{
3 O PODER POLÍTICO DO JUDICIÁRIO DO ESTADO BEM- ESTAR AO ESTADO DEMOCRÁTICO DE DIREITO
}

O Estado Liberal, entretanto, viu-se em xeque. O seu marcante individualismo, inserido no contexto da Revolução Industrial e dos conflitos por ela ocasionados, fez eclodir uma nova ordem política, jurídica e social, ressignificando, mais uma vez, o Poder Judiciário.

Surge, então, o Estado Bem-Estar,

\begin{abstract}
[...] activamente envolvido na gestão dos conflitos e consertações entre classes e grupos sociais, e apostado na minimização possível das desigualdades sociais no âmbito do modo de produção capitalista dominante nas relações econômicas. A consolidação do Estadoprovidência significou a expansão dos direitos sociais e, através deles, a integração das classes trabalhadoras nos circuitos do consumo anteriormente fora do seu alcance (SANTOS, 1986, p. 16).
\end{abstract}

Ao lado da expansão de direitos sociais das classes até então à margem da atuação estatal, a emersão desse Estado-providência esteve ligada a fatores até ali desconhecidos, como as relações de trabalho, a inclusão da mulher no mercado, entre outros fatores que passaram a ocupar a pauta das ações do Estado e das relações sociais (SANTOS, 1986, p. 16).

Entretanto, apesar de o Estado Bem-Estar ter reconhecido uma nova série de direitos, especialmente os sociais, a estruturação estatal não foi proporcional ao reconhecimento desses direitos, revelando o descompasso entre recognição e efetivação. Acresça-se, também, o aumento dos conflitos sociais e a crescente busca pela satisfação dessa parcela de direitos recém-conquistados (SANTOS, 1986, p. 16). Tem-se, pois, o declínio do welfare state e o surgimento de uma nova ordem, fundada em premissas democráticas. 
O Poder Judiciário passou, então, a ser encarado como natural destinatário dessas novas demandas envolvendo a conflituosidade social emergente e os direitos não efetivados pelo Estadoprovidência, bem como as demandas e aspirações não satisfeitas. $\mathrm{O}$ resultado, como ensina Boaventura de Sousa Santos, é a "explosão de litigiosidade" (SANTOS, 1986, p. 16), fenômeno mundial5, agravado, ainda, por uma recessão econômica em recrudescimento, sobretudo a partir da década de 1970.

Nessa transição do Estado Bem-Estar para o Estado Democrático de Direito - na Europa, pós-segunda guerra e, no Brasil, a partir de 1988 - viu-se que os centros de administração da justiça não se mostraram aptos a salvaguardar esses direitos recémconquistados com o Estado Bem-Estar, nem a oferecer uma justiça compatível com a nova demanda, ou mesmo responsiva às novas relações sociais.

E toda essa “[...] 'juridificação' da vida moderna [...]" (HIRSCHL, 2006, p. 724, tradução nossa) ${ }^{6}$ tem claros impactos. Atualmente o Brasil - que não é exceção - também enfrenta grandes problemas ligados à explosão da litigiosidade, acrescidos, ainda, de questões referentes à chamada primeira onda renovatória7, isto é, do acesso formal à justiça. Dados da pesquisa Justiça em Números (CONSELHO..., 2016, p. 17), ano-base 2015, mostram que o montante de casos que o Poder Judiciário precisou lidar durante o ano ${ }^{8}$, entre os já resolvidos e os não resolvidos, passou de 100

\footnotetext{
$5 \mathrm{Na}$ Alemanha, por exemplo, a explosão da litigiosidade foi metaforicamente descrita como "enchente de processos" (Prozeßflut). Cf. SABADELL, 2013.

${ }^{6}$ Texto original: “[...] 'juridification' of modern life [...]”.

7 Preferiu-se, no presente trabalho, a adoção do termo "acesso à justiça", não obstante as críticas sobre o caráter plurissignificativo do termo, muito bem expostas por Rosemiro Pereira Leal (LEAL, 2014, p. 54). A escolha funda-se na maior difusão do termo "acesso à justiça" e por representar a exata citação de Boaventura de Sousa Santos, marco teórico sociológico adotado no presente tópico. 8 Ao longo dos anos o relatório "Justiça em Números" do Conselho Nacional de Justiça vem sofrendo mudanças na metodologia de cálculo, com adaptações e modificações de fórmulas e de indicadores. A partir do ano-base 2015 o termo "processos que tramitaram", por exemplo, que nos relatórios anteriores "[...] se referia à soma dos casos novos e pendentes, passou a ser computado pela soma dos casos baixados e pendentes." (CONSELHO..., 2016, p. 42). Já a taxa de
} 
milhões em 2014 para 102 milhões em 2015, finalizando o ano de 2015 com quase 74 milhões de processos em tramitação. Já a taxa de congestionamento obtida nesse levantamento alcançou $72,2 \%$. No ano-base 2016, ainda segundo dados da pesquisa Justiça em Números (CONSELHO..., 2017), o Poder Judiciário finalizou o ano "[...] com 79,7 milhões de processos em tramitação [...]" (CONSELHO..., 2017, p. 65). A taxa de congestionamento, que sempre se manteve em altos patamares, sempre acima de 70\%, em 2016 registrou "[...] aumento de 0,2 ponto percentual." (CONSELHO..., 2017, p. 76).

Assim, o papel político do Judiciário no Estado Democrático, ultrapassou a mera invalidação de atos dos outros Poderes que invadissem competências dos demais, passando a aferição da constitucionalidade a ter um prisma de concreção de direitos e garantias fundamentais. Luiz Moreira (2006), discorrendo acerca da centralidade dos direitos fundamentais no Estado Democrático de Direito, destaca que

[...] tanto na Filosofia quanto no Direito, há um consenso de que a tarefa específica do Estado consiste em efetivar e institucionalizar os direitos fundamentais. Por que efetivar e institucionalizar? Porque quem dispõe da faculdade de efetivar, pode negar-se a realizar tal tarefa. Daí porque é preciso mais do que a tarefa de efetivação. É necessário que a estrutura estatal seja concebida como instituição dos direitos fundamentais (MOREIRA, 2006, p. 150).

O Poder Judiciário assume, assim, o contorno político de gestor de crises e, dentre tantas, de uma importante crise paradigmática, sublinhada pela aproximação do Direito e moral, vista por muitos como chave para a transformação das crenças que circundam as verdades científicas, "[...] sustentadas em período de normalidade ou de matrizes estabelecidas" (SAMPAIO, 2006, p. xiii). Soma-se a isso o contexto de escassez e da já destacada 
O Poder Político Do Judiciário: Uma Análise Histórica, Jurídica...

conflituosidade, além de fenômenos como a polarização de grupos 9 e a busca pela efetivação de direitos fundamentais.

\subsection{A FUNÇÃO POLÍTICA DO JUDICIÁRIO NO PÓS-POSITIVISMO}

Para compreender esse processo de crise paradigmática e abertura valorativa do processo decisório, marcantes do póspositivismo, e consequente redefinição do papel político do Judiciário nos tempos atuais, é preciso retomar a ligação entre correntes positivistas e pós-positivistas. Entre tantos autores e teorias contrastantes, marcante foi, no século XIX, o pensamento da Escola Histórica e seus expoentes, Friedrich Karl von Savigny e Georg Friedrich Puctha, e as críticas a ela feitas por Rudolf von Ihering.

Para a Escola Histórica e a doutrina da jurisprudência dos conceitos, o Direito deveria se estruturar em um sistema lógico de conceitos, construído segundo as regras da lógica formal. Para Puchta,

[...] cada conceito superior autoriza certas afirmações (por ex., o conceito de direito subjectivo é de que se trata de 'um poder sobre um objeto'); por conseguinte, se um conceito inferior se subsumir ao superior, valerão para ele 'forçosamente' todas as afirmações que se fizerem sobre o conceito superior (para o crédito, como uma espécie de direito subjectivo, significa isto, por ex., que ele é um "poder sobre um objecto que esteja sujeito à vontade do credor e que se poderá então vislumbrar, ou na pessoa do devedor, ou no comportamento devido por este último"). A 'genealogia dos conceitos' ensina, portanto, que o conceito supremo, de que se deduzem todos os outros, codetermina os restantes através do seu conteúdo (LARENZ, 1997, p. 25, grifos nossos).

\footnotetext{
9 A respeito, Cass Sunstein diz que a polarização de grupos é um padrão típico de grupos deliberativos, podendo ser observada em diversos países, constituindo "uma grande lição sobre o comportamento dos consumidores, de grupos de interesse, de mercado imobiliário, de organizações religiosas, de partidos políticos, de movimentos de libertação, de órgãos do governo, do poder legislativo, dos racistas, de painéis judiciais, daqueles que promovem a paz, daqueles que fazem a guerra $\mathrm{e}$ até de nações inteiras." (SUNSTEIN, 2010, p. 4-5).
} 
Desse modo, a Escola Histórica e seu formalismo baseavam-se em critérios gramaticais, lógicos, históricos e sistemáticos da interpretação jurídica, tudo na tentativa de obter a vontade do legislador histórico, o que seria o fim desejado da interpretação.

Ihering, em franca oposição a esse formalismo, sobretudo a Savigny, rompe com essa lógica enclausurada e determina uma orientação não formal do Direito. Na obra $O$ Espírito do Direito Romano (IHERING, 1877), Ihering tecia agudas críticas à chamada jurisprudência dos conceitos da Escola Histórica. Para ele, o Direito falhava em não responder adequadamente aos anseios sociais. Sob tal premissa, passou a defender um fim às proposições jurídicas, de modo que o conteúdo normativo revelasse uma função social (LAUDA, 2009).

Ihering estrutura seu pensamento afirmando que "[...] o erro da escola histórica teria consistido em sua defesa do caráter nacional, do volksgeist ${ }^{10}$ relativo ao Direito como elemento fundamental" (LAUDA, 2009, p. 4), ou seja, do costume como elemento mais importante do que a lei. Nota-se no pensamento maduro de Ihering certa influência utilitarista, sobretudo no desenvolvimento do conceito de interesse. Para ele, a luta é o meio pelo qual o direito consegue a paz (IHERING, 1999, p. 1), além de estabelecer que os direitos são interesses juridicamente protegidos, i.e., a substância do direito é a utilidade (MEULENAERE, [19--], p. 8).

Em posição nitidamente similar, Jeremy Bentham (17481832), desenvolveu o princípio (ou teoria) da utilidade, assim conceituado:

Por princípio de utilidade entende-se aquele princípio que aprova ou desaprova qualquer ação, segundo a tendência que tem a aumentar ou diminuir a felicidade da pessoa cujo interesse está em jogo, ou, o que é a mesma coisa em outros termos, segundo a tendência a promover ou comprometer a referida felicidade. [...]

\footnotetext{
10 "Atitude mental, espírito, gênio, temperamento dominante de uma época, [...] de
} um povo." (INWOOD, 1997, p. 117). 
O Poder Político Do Judiciário: Uma Análise Histórica, Jurídica...

$$
\begin{aligned}
& \text { [...] } \\
& \text { III - O termo utilidade designa aquela propriedade } \\
& \text { existente em qualquer coisa, propriedade em virtude da } \\
& \text { qual o objeto tende a produzir ou proporcionar benefício, } \\
& \text { vantagem, prazer, bem ou felicidade (tudo isto, no caso } \\
& \text { presente, se reduz à mesma coisa), ou (o que novamente } \\
& \text { equivale à mesma coisa) a impedir que aconteça o dano, a } \\
& \text { dor, o mal, ou a infelicidade [...]. (BENTHAM, 1979, p. 6). }
\end{aligned}
$$

Entretanto, a jurisprudência dos interesses de Ihering acabou por se ligar a posições pós-positivistas extremadas, a exemplo da escola do Direito Livre, do início do século XX, que defendia "[...] a plena liberdade do juiz no momento de decidir os litígios, podendo, até mesmo, confrontar o que reza a lei" (STRECK, 2015), ou a de adeptos de uma teoria idiossincrática do realismo jurídico norteamericano que, para além da premissa "de que juízes primeiramente decidem e depois engendram modelos de dedução lógica” (GODOY, 2013, p. 5), restringe-se à personalidade do juiz ao afirmar que o Direito é o que o juiz diz que é.

\section{O PAPEL POLÍTICO DO JUDICIÁRIO A PARTIR DO SÉCULO XX E SOB A ÓPTICA DA SOCIOLOGIA DA ADMINISTRAÇÃO DA JUSTIÇA}

Tendo como ponto de partida os centros de administração judiciária e o sistema judicial, a Sociologia da Administração da Justiça trouxe grandes contribuições para a compreensão dos tribunais como um subsistema do sistema político global a partir do século XX, como ensina Boaventura de Sousa Santos (1986). Sob esse estrito enfoque sociológico, as decisões, ou outputs, passaram a ser entendidos como resultado de diversos estímulos, interferências sociais e políticas, isto é, os inputs, contribuindo, assim, para o "[...] fim do mito da neutralidade dos tribunais" (SANTOS, 1986, p. 11). 
Em consequência, os juízes passaram a ocupar o centro de diversas análises, sendo as decisões "[...] uma variável dependente cuja aplicação se procurou nas correlações com as variáveis independentes" (SANTOS, 1986, p. 13), ou seja, as condições e pressões sociais, políticas que incidem sobre os magistrados.

Há, ainda, outra consequência da compreensão dos tribunais como um subsistema do sistema político global, como afirma Boaventura de Sousa Santos (1986). Essa consequência está em "[...] desmentir por completo a ideia convencional da administração da justiça como uma função neutra protagonizada por um juiz apostado apenas em fazer justiça acima e equidistante dos interesses das partes" (SANTOS, 1986, p. 13).

Confirmam essa tese as diversas pesquisas desenvolvidas a partir do século XX que tentaram classificar ou mesmo mapear posições e interferências políticas no processo decisório. Na década de 1960, cita Boaventura de Sousa Santos (1986), os estudos de Glendon A. Schubert (1960), nos Estados Unidos, buscaram fazer uma distinção entre juízes liberais e conservadores, correlacionando suas posições políticas com suas decisões.

Ainda nos Estados Unidos, os estudos do professor da Harvard Law School, Cass Robert Sunstein, têm contribuído para a identificação da inclinação política dos juízes e suas decisões. Na obra Are judges political? An empirical analysis of the federal judiciary (2006), em coautoria com David Schkade, Lisa M. Ellman e Andres Sawicki, Sunstein pretende verificar três diferentes hipóteses a partir de uma análise empírica dos juízes das Court Appeals, suas decisões e o partido que os indicou para o cargo. A primeira, chamada "ideological voting" (SUNSTEIN et al., 2006, p. 8), em tradução livre, "voto ideológico" em que, nos casos controversos, uma tendência ideológica do juiz pode ser prevista pelo partido do presidente que nomeia o magistrado. A segunda, chamada "ideological dampening" (SUNSTEIN et al., 2006, p. 8), em tradução livre, "atenuação ideológica", ou seja, a suscetibilidade de moderação 
O Poder Político Do Judiciário: Uma Análise Histórica, Jurídica...

da tendência ideológica do juiz quando, no julgamento colegiado, estiver acompanhado de dois juízes indicados por um partido diferente ${ }^{11}$. E, por fim, a terceira e última hipótese, chamada "ideological amplification" (SUNSTEIN et al., 2006, p. 9), em tradução livre, "ampliação ideológica", isto é, uma tendência de, também nos casos mais controversos, o juiz ter suas preferências ideológicas expandidas quando acompanhado por juízes indicados pelo mesmo partido.

A pesquisa mostra relevantes resultados, como o que identifica que juízes indicados pelo Partido Democrata mostram mais suscetibilidade de sofrer o chamado ideological dampening se comparados com os indicados republicanos, além de mais propensos à ideological amplification (SUNSTEIN et al., 2006, p. 10).

Já em Constitutional Personae (2015), Cass R. Sunstein classifica e esmiúça as quatro personae ou perfis de juízes, que se revelam na Suprema Corte norte-americana: os heróis, os soldados, os minimalistas e os mudos. Sunstein (2015, p. xv) afirma que muitas pessoas são atraídas a uma determinada abordagem não por causa das razões ou argumentos oferecidos em seu favor, mas pelo perfil (ou persona) assumido pelos juízes em razão da ação de determinada abordagem.

Sunstein (2015, p. 3) explica que essas personae são, ao mesmo tempo, abstratas e estilizadas, pois nenhum juiz do mundo real apresenta, exclusivamente, um ou outro perfil. Em verdade, os juízes associam-se aos perfis em determinadas ocasiões ou mostram uma tendência em adotar determinado perfil nos casos mais importantes e desafiadores. Destaca, também, que esses quatro perfis podem ser adotados durante uma carreira ou mesmo durante um curto espaço de tempo. E a adoção de um perfil não precisa ser oportunista ou manipuladora; geralmente é reflexo autêntico do

${ }^{11}$ Um juiz indicado pelo partido democrata, tendo como pares dois juízes indicados pelo partido republicano e vice-versa (SUNSTEIN et al., 2006, p. 9). 
papel que resulta da teoria da intepretação preferida do juiz (SUNSTEIN, 2015, p. 3).

No Brasil, também, é possível encontrar diversos estudos acerca do papel político do Poder Judiciário, a exemplo da pesquisa $A$ quem interessa o controle concentrado de constitucionalidade? (COSTA; BENVINDO, 2014), que fomenta a discussão do sistema de controle concentrado para além de avaliações triviais, partindo de análise da prática cotidiana desenvolvida pelo Supremo Tribunal Federal no exercício do controle concentrado de constitucionalidade, apresentando, como conclusão, que antes de funcionar como salvaguarda de direitos e garantias fundamentais, o controle concentrado de constitucionalidade representa instrumento de defesa de interesses nitidamente corporativos, divorciando o discurso doutrinário da prática judicial cotidiana.

\section{CONCLUSÃo}

Compreender a relevância e o papel que o Poder Judiciário exerce na atualidade, remete a uma ampla digressão que, como visto, necessita ser feita em bases interdisciplinares. $\mathrm{O}$ entendimento do fim do mito da neutralidade do Judiciário (SANTOS, 1986, p. 11), só se revela por completo quando se remonta à definição e ao desenvolvimento dos Poderes estatais, modernamente elaborados por Montesquieu e de intensa presença na definição política dos Estados contemporâneos. A Ciência Política, ao oferecer uma visão analítica dos padrões de funcionamento e da relação e dimensão dos Poderes - inclusive no seu aspecto histórico - e a visão holística proporcionada pela Sociologia da Administração da Justiça, trazem nova luz aos institutos jurídicos e à função jurisdicional. 
O Poder Político Do Judiciário: Uma Análise Histórica, Jurídica...

Como visto, o período absolutista implicou um papel dos juízes e um modelo de justiça sem a configuração de poder político autônomo, em razão da intensa vinculação à vontade do monarca. Tal panorama começa a se alterar a partir da Revolução Francesa e da Constituição dos Estados Unidos, em 1789.

No entanto, apesar de, após a queda dos regimes absolutistas, defenderem a bandeira da separação dos Poderes, França e Estados Unidos experimentaram caminhos diferentes na formatação do Poder Judiciário. Com um Poder Legislativo forte e um Executivo enfraquecido, o Judiciário, na França, acabou reduzido à condição de uma reunião de "[...] seres inanimados [...]" (MONTESQUIEU, 2000, p. 175) que não podiam moderar nem a força, nem o rigor da lei. Nos Estados Unidos, no entanto, o medo de uma tirania da maioria e a descentralização do poder, deu ao Judiciário feições políticas marcantes, conferindo-lhe, segundo Tocqueville (2000), posição de destaque na sustentação da democracia norte-americana, exercendo o efetivo contrapeso dos demais Poderes, sendo o judicial review o mais vigoroso exemplo.

Com o esgotamento do Estado Liberal, o surgimento do Estado Bem-Estar e, posteriormente, a transição para o Estado Democrático, o poder político do Judiciário ganha novo ângulo, em razão do surgimento de novas relações sociais e de trabalho, da "explosão de litigiosidade" (SANTOS, 1986, p. 16), e da tentativa de compatibilizar a crescente demanda dos indivíduos a uma oferta harmônica de justiça.

Além disso, a aproximação entre Direito e moral no póspositivismo, acrescenta a esse papel político do Judiciário uma crise paradigmática, ensejando a abertura valorativa do processo decisório e despertando a importância dos estudos sociológicos dos tribunais como um subsistema do sistema político global (SANTOS, 1986, p. 23).

Nesse contexto histórico, jurídico, político e sociológico, demonstrou-se que a existência e a dimensão do poder político do 
Judiciário variam conforme o paradigma do Direito, ou seja, conforme a transição, na modernidade, do Estado Liberal ao Estado Democrático, mediado pelo Estado Bem-Estar, o que confirma a hipótese da pesquisa.

Na contemporaneidade, a aproximação entre Direito e moral amplia o horizonte de definição do poder político do Judiciário, sobretudo pela tentativa perene de se construir uma tradição constitucional democrática capaz de balizar o processo decisório. Logo, aprofundar o entendimento acerca da definição e amplitude desse poder político significa revelar a atuação democrática do Judiciário e, em última análise, entender até que ponto as ideologias políticas alteram o perfil dos juízes e o conteúdo de suas manifestações e, consequentemente, o almejado curso democrático de um Estado.

Data de Submissão: 25/02/2018

Data de Aprovação: 21/04/2018

Processo de Avaliação: double blind peer review

Editor Geral: Jailton Macena de Araújo

Editor de Área: Fernando Joaquim Ferreira Maia

Assistente de Edição: Ilina Cordeiro de Macedo Pontes

\section{REFERÊNCIAS}

ARANTES, Rogério Bastos. Judiciário: entre a justiça e a política. In: AVELAR, Lúcia; Antônio CINTRA, Octávio (Org.). Sistema político brasileiro: uma introdução. 2 ed. rev. e ampl. São Paulo: Unesp, 2007, p. 81-115.

BARROSO, Luís Roberto. Constituição, Democracia e Supremacia Judicial: Direito e Política no Brasil Contemporâneo. Revista da Faculdade de Direito da UERJ, Rio de Janeiro, v. 2, n. 21, 
O Poder Político Do Judiciário: Uma Análise Histórica, Jurídica...

jan./jun. 2012. Disponível em: <http://www.epublicacoes.uerj.br/index.php/rfduerj/article/view/1794>. Acesso em: 27 set. 2017.

BENTHAM, Jeremy. Uma introdução aos princípios da moral e da legislação. Trad. de Luiz João Baraúna. 2. ed. São Paulo: Abril Cultural, 1979.

CAMUS, Sébastien et al. 100 obras-chave de filosofia. Trad. de Lúcia Mathilde. 4. ed. Petrópolis: Vozes, 2014.

CARVALHO, Kildare Gonçalves. Direito Constitucional: teoria do Estado e da Constituição; Direito Constitucional positivo. 17. ed. Belo Horizonte: Del Rey, 2011.

CONSELHO NACIONAL DE JUSTIÇA. CNJ. Justiça em números 2016: ano-base 2015. Brasília, 2016. Disponível em: <http://www.cnj.jus.br/files/conteudo/arquivo/2016/10/b8f46be3d bbff344931a933579915488.pdf >. Acesso em: 5 nov. 2017.

CONSELHO NACIONAL DE JUSTIÇA. CNJ. Justiça em números 2017: ano-base 2016. Brasília, 2017. Disponível em: <http://www.cnj.jus.br/files/conteudo/arquivo/2017/o9/904fo97f2 15cf19a2838166729516b79.pdf >. Acesso em: 5 nov. 2017.

COSTA, Alexandre; BENVINDO, Juliano Zaiden. A quem interessa o controle concentrado de constitucionalidade? O Descompasso entre Teoria e Prática na Defesa dos Direitos Fundamentais. Brasília, 2014. Disponível em: <http://dx.doi.org/10.2139/ssrn.2509541>. Acesso em: 27 set. 2017.

ESTADOS UNIDOS DA AMÉRICA. Departamento de Estado. Perfil do sistema judiciário dos EUA. [S.l.: s.n.], 2006.

GODOY, Arnaldo Sampaio de Moraes. Introdução ao realismo jurídico norte-americano. Brasília, 2013.

GRISSAULT, Katy. 50 autores-chave de filosofia... e seus textos incontornáveis. Trad. de João Batista Kreuch. Petrópolis: Vozes, 2012. 
GUSTIN, Miracy Barbosa de Sousa; DIAS, Maria Tereza Fonseca.

(Re)pensando a pesquisa jurídica: teoria e prática. 4. ed. rev. e atual. Belo Horizonte: Del Rey, 2015.

HIRSCHL, Ran. The New Constitutionalism and the Judicialization of Pure Politics Worldwide. Fordham Law Review, [s.l.], v. 75, n. 2, p. 721-754. 2006. Disponível em:

<https://ssrn.com/abstract=951610 > . Acesso em: 27 set. 2017.

IHERING, Rudolf von. L'esprit du droit roman dans les diverses phases de son développment. Trad. franc. de Octave de Meulenaere. Paris: A. Marescq, 1877.

IHERING, Rudolf von. A evolução do direito. Trad. Abel d'Azevedo. Lisboa: José Bastos e Cia., [19--]. Vertido da tradução francesa de Octave de Meulenaere. Disponível em: <http://bdjur.stj.jus.br//jspui/handle/2011/20438>. Acesso em: 27 set. 2017.

IHERING, Rudolf von. A luta pelo Direito. Trad. de João de Vasconcelos. 17. ed. Rio de Janeiro: Forense, 1999.

INWOOD, Michael. Dicionário Hegel. Trad. de Álvaro Cabral. Rio de Janeiro: Zahar, 1997.

KUHN, Thomas S. A estrutura das revoluções científicas. 5. ed. São Paulo: Perspectiva, 1998.

LARENZ, Karl. Metodologia da Ciência do Direito. Trad. de José Lamego. 3. ed. Lisboa: Fundação Calouste Gulbenkian, 1997.

LAUDA, Bruno Bolzon. Influências em Ihering: investigação dos fundamentos de seu pensamento em sua fase madura. Revista Eletrônica do Curso de Direito, Santa Maria, v. 4, n. 3, 2009. Disponível em:

<https://periodicos.ufsm.br/revistadireito/article/view/7037/4254\# .WDOszdUrLIU>. Acesso em: 27 set. 2017.

LEAL, Rosemiro Pereira. Teoria geral do processo: primeiros estudos. 12. ed. rev. e atual. Rio de Janeiro: Forense, 2014. 
O Poder Político Do Judiciário: Uma Análise Histórica, Jurídica...

LOCKE, John. Carta acerca da tolerância; segundo tratado sobre o governo; ensaio acerca do entendimento humano. 2 ed. São Paulo: Abril Cultural ,1978.

MADISON, James; HAMILTON, Alexander; JAY, John. Os artigos federalistas, 1787-1788. Trad. Maria Luíza X. de A. Borges. Rio de Janeiro: Nova Fronteira, 1993.

MAUS, Ingeborg. Judiciário como superego da sociedade: O papel da atividade jurisprudencial na "sociedade órfã". Trad. de Martonio Lima e Paulo Albuquerque. Revista Novos Estudos, São Paulo: Cebrap, n. 58, p. 183-202, nov. 2000.

MEULENAERE, Octave de. Prefácio. In: IHERING, Rudolf von. A evolução do direito. Trad. Abel d'Azevedo. Lisboa: José Bastos e Cia., [19--]. Vertido da tradução francesa de Octave de Meulenaere. Disponível em: <http://bdjur.stj.jus.br//jspui/handle/2011/20438>. Acesso em: 27 set. 2017.

MONTESQUIEU, Barão de. O espírito das leis. Trad. de Cristina Murachco. São Paulo: Martins Fontes, 2000.

MOREIRA, Luiz. Direito e política. In: SAMPAIO, José Adércio Leite (Org.) Constituição e crise política. Belo Horizonte: Del Rey, 2006, p. 149-157.

\section{SABADELL, Ana Lúcia. Manual de Sociologia Jurídica:}

introdução a uma leitura externa do direito. 6. ed. rev., atual. e ampl. São Paulo: Revista dos Tribunais, 2013.

SAMPAIO, José Adércio Leite. Introdução e bricolagem sobre constituição e crise política. In: SAMPAIO, José Adércio Leite (Org.) Constituição e crise política. Belo Horizonte: Del Rey, 2006, p. xiii.

SANTOS, Boaventura de Sousa. Introdução à Sociologia da Administração da Justiça. Revista Crítica de Ciências Sociais, Coimbra, n. 21, p. 11-37, nov. 1986. Disponível em: $<$ http://www.ces.uc.pt/rces/includes/download.php?id=298>. Acesso em: 27 set. 2017. 
SÉROUSSI, Roland. Introdução ao direito inglês e norteamericano. Trad. de Renata Maria Parreira Cordeiro. São Paulo: Landy, 2006.

SOARES, Guido Fernando Silva. Common law: introdução ao direito dos EUA. 2. ed. São Paulo: Revista dos Tribunais, 2000.

STRECK, Lenio Luiz. O Brasil revive a Escola do Direito Livre! E dá-lhe pedalada na lei! Consultor Jurídico, São Paulo, 25 jun. 2015. Disponível em: <http://www.conjur.com.br/2015-jun25/senso-incomum-brasil-revive-escola-direito-livre-lhe-pedaladalei >. Acesso em: 27 set. 2017.

SUNSTEIN, Cass R. Radical in Robes: why extreme right-wing courts are wrong for America. New York: Basic Books, 2005.

SUNSTEIN, Cass R. A era do radicalismo: entenda por que as pessoas se tornam extremistas. Trad. de Lucienne Scalzo. Rio de Janeiro: Elsevier, 2010.

SUNSTEIN, Cass R. Constitutional personae. New York: Oxford University Press, 2015.

TOCQUEVILLE, Alexis de. O antigo regime e a Revolução. Trad. de Yvonne Jean. 4. ed. Brasília: Universidade de Brasília, 1997.

TOCQUEVILLE, Alexis de. A democracia na América: sentimentos e opiniões. Trad. de Eduardo Brandão. São Paulo: Martins Fontes, 2000. 


\title{
The Political Power Of The Judiciary Branch: A Historical, Legal, Political And Sociological Analysis From Liberal State To The Democratic State Of Law
}

\author{
Bruno Paiva Bernardes \\ Eduardo Martins de Lima
}

\begin{abstract}
The present article, whose investigation takes place in the juridicalsociological aspect and having the predominant reasoning the inductive-deductive and the dialectical, has its theme the political power of the Judiciary branch from the end of the Modern Age to the contemporaneousness. As research matter, and adding the Political Science perspective to the legal definitions and historical events, it questions the interference of the patterns of political organization in the establishment and delimitation of the political power of the Judiciary, as well as the ideological influences on legal thought. It aims to investigate and size the political power of the Judiciary since the period immediately preceding the French Revolution and the US Constitution, until the emergence of the Democratic State of Law, contextualizing, political and sociological studies on the profiles of judges and the decision-making process. It asserts, as a hypothesis, that the existence and the dimension of the political power of the Judiciary branch vary according to the legal paradigm.
\end{abstract}

Keywords: History of law. Judiciary Branch. Political power. Political Science. Politics. 